\title{
ANTIMICROBIAL, ANTIOXIDANT AND SOME BIOCHEMICAL PROPERTIES OF VACCINIUM VITIS-IDAEA L.
}

\author{
M.V. Kryvtsova ${ }^{1}$, K. Trush ${ }^{1}$, J. Eftimova ${ }^{2}$, J. Koščová2, M.J. Spivak ${ }^{3}$ \\ ${ }^{1}$ Uzhhorod National University, 32 Voloshyn str., Uzhhorod, 88000, Ukraine \\ ${ }^{2}$ University of Veterinary Medicine and Pharmacy in Košice, \\ 73 Komenský str., Košice, 04181, Slovakia \\ ${ }^{3}$ Zabolotny Institute of Microbiology and Virology, NAS of Ukraine, \\ 154, Zabolotny str., Kyiv, 03143, Ukraine \\ e-mail: maryna.krivcova@gmail.com
}

Over the past years there has been a growing interest to vegetable raw materials evaluated from the viewpoint of their potential antimicrobial activity. Vaccinium genus plants are known to contain a whole spectrum of biologically active substances with anti-inflammatory, antidiabetic, gene-protective, antioxidant and antimicrobial properties. The purpose of the work was to study the antimicrobial, antioxidant and some biochemical properties of alcoholic extracts of fruit and leaves of Vaccinium vitis-idaea L., gathered in the Ukrainian Carpathians. Methods. The plants for the study were gathered around the village of Pylypets, Mizhhiria rayon, Zakarpatska oblast (Transcarpathia). From the fruit and leaves, ethyl and methyl extracts were produced. The subjects for study were their antioxidant activity (by DPPH method), total tannin and flavonoids (by spectrophotometric method), and antimicrobial activity (by diffusion-into-agar method). For the purpose of study, type and clinical isolates were used from the oral cavity of human patients suffering from inflammatory diseases of periodontium, characterized by wide resistance spectrum to antibiotics. Results. The reviewed extracts were observed to have a higher antimicrobial activity against Gram-positive bacteria. The highest antimicrobial activity was shown by the extract of Vaccinium vitis-idaea L. fruit. Its antimicrobial activity was registered upon both test and clinical isolates of S.aureus, including methicillin-resistant ones. The ethyl fruit extract and methanol leaf extract were established to show high antimicrobial effect upon S.pyogenes. The ethanol fruit and leaf extracts and methanol fruit extract were observed to show weak antimycotic activity. The extracts were characterized by high antioxidant activity, with the highest effect peculiar for ethyl leaf and fruit extracts, and somewhat lower one for methyl extracts. The ethanol fruit extract was characterized by the highest tannin level out of all extracts under review. Conclusions. The antimicrobial and high antioxidant activity of the ethanol extract of Vaccinium vitis-idaea L. fruit and leaves, and absence of the antimicrobial effect against the probiotic strain of Lactobacillus plantarum, characterized by the antagonistic activity against opportunistic microorganisms, cause the advisability of their complex application as the basis for phytobiotics.

Keywords: antimicrobial properties, antioxidant activity, flavonoids, tannins, Vaccinium vitis-idaea $L$.

At a time when there is a growing trend to the formation of antibioticresistant strains of microorganisms, the development of new approaches, means and methods of correction of the organism's facultative microbiota acquires a peculiar importance. Medicinal plants look especially appealing in this respect. Over the past years there has been a growing interest to vegetable raw materials evaluated from the viewpoint of their potential antimicrobial activity. Medicinal 
plants have traditionally been used both in folk and official medicine. The antimicrobial properties of the plants' components may in many cases serve as an alternative to antibiotics, especially as preventive means. At the same time, plants are a source of a wide spectrum of biologically active substances (alkaloids, glycosides, terpenoids, saponins, flavonoids, coumarins, kinones, peptides); they show a high antioxidant activity and anti-inflammatory and immune-modulating properties. Another advantage of plant-based materials is that apart from showing antimicrobial properties, they may serve as a vitamin complex and natural growth promoters. A significant number of studies have been dedicated to antibacterial properties of vegetable extracts. For instance, a number of plants used in Belarusian folk medicine show an expressed bactericidal effect against both antibiotic-sensitive and extremely antibioticresistant isolates of nonfermenting Gram-negative bacteria: the antibacterial effect has been established for Eucalyptus viminalis and Quercus robur against $P$. aeruginosa, of aqueous extract of bearberry against $A$. baumanii [1].

We showed the efficiency of the use of conifer needles as a phytoenergetic additive in veterinary [2]; of the antimicrobial activity of chlorophilippin ( $5 \%$ alcohol solution), received from the gummy mass of green pigments of conifer needles of Pinus sylvestris [3]. To date, the antimicrobial properties against opportunistic strains have been shown for Calendula officinalis, roots of Cichorium intybus and leaves of Portulaca oleracea [4]; some of the medicinal plants growing in India (Justicia adhatoda, Zingiber offcininale, Allium sativum, Embilica officinalis, Lawsonia inermis, Ocimum sanctum, Myristica fragrans, Rauwolfia serpentine, Lawsonia inermis) [5]; the antimicrobial activities of Artemisia plant extracts against oral pathogens [6], and antibacterial activity of Inula viscosa L. and Aloysia citriodora Palau $A$. against Gram-positive bacteria such as $B$. subtilis and $S$. aureus [7] have been established. The multi-factorial character of the influence of medicinal plants upon organism shows their potential as a source of substances with antimicrobial activity upon extra-antibiotic-resistant microorganisms.

The purpose of the study was to explore the antimicrobial, antioxidant and some biochemical properties of alcoholic extracts of fruit and leaves of Vaccinium vitis-idaea $L$.

Materials and methods. The plant materials were collected in the vicinity of the village of Pylypets, Mizhhiria rayon, Zakarpatska oblast (Trancarpathia), dried at the temperature of $30-35^{\circ} \mathrm{C}$ in shadow, then ground and placed in tightly closed containers.

Extracts manufacturing techniques. We made ethyl and methyl extracts of ftuit and leaves of Vaccinium vitis-idaea $L$. A $10 \mathrm{~g}$ batch of dry plant material was pulverized to powdery mass. In an Erlenmeyer flask, $10 \mathrm{~g}$ of plant material was blended with $200 \mathrm{ml}$ of or $96^{\circ}$ ethyl or methyl alcohol (Sigma, Germany). The opening was closed with a food wrap to avoid evaporation. Following a 30-minute-long incubation in the ultrasonic bath (Kraintek) at $35^{\circ} \mathrm{C}$, the blend was filtered through Whatman No. 1 filter paper. The clear solution was placed in an evaporative device (16-17/32" x 34-59/64" G5B, Coated Dry Ice Condenser Rotary Evaporator) to obtain pure alcoholic extract at $50{ }^{\circ} \mathrm{C}$, $82 \mathrm{rpm}$. Then, extracts were subjected to evaporation under reduced pressure at $40{ }^{\circ} \mathrm{C}$ in order to remove or ethyl or methyl. As a result, the following 
pure extracts were obtained: ethyl extract of Vaccinium vitis-idaea L. fruit $2.505 \mathrm{~g}$; of Vaccinium vitis-idaea L. leaves - $1.218 \mathrm{~g}$; methyl extract of Vaccinium vitis-idaea L. fruit - $1.536 \mathrm{~g}$; of Vaccinium vitis-idaea L. leaves $1.306 \mathrm{~g}$.When the alcohol evaporated, $10 \mathrm{ml}$ of ethyl (methyl) alcohol were added to the pure extract left on the bottom of the flask.

As test cultures, the following bacteria and yeasts from the American Type Culture Collection were used: Candida albicans ATCC 885-653; Staphylococcus aureus ATCC 25923; Escherichia coli ATCC 25922; Enterococcus faecalis ATCC 29212; Streptococcus pyogenes ATCC 19615. We also used clinical strains of bacteria and yeasts ( $S$. aureus, E. coli, $S$. pyogenes, $C$. albicans) isolated from the oral cavities of patients suffering from inflammatory periodontium. From the oral cavities of 155 patients were isolated microorganisms characterised by resistance to at least 10 antibiotic preparations belonging to two and more classes: $S$. aureus (28 isolates), E. coli (11 isolates), S. pyogenes (25 isolates), C. albicans (17 isolates).

We chose the clinical strains with multiple resistance to antibiotics. A probiotic strain of Lactobacillus plantarum L. was used in the study [8].

The microorganisms from the oral cavities of patients with chronic periodontium inflammatory processes were isolated on the basis of the Dental Polyclinic, Uzhhorod National University; the extracts were manufactured and their antioxidative activity and contents of tannins and flavonoids were determined on the basis of the Department of Pharmacognosy and Botany, ${ }^{2}$ University of Veterinary Medicine and Pharmacy in Košice, Slovakia; the antimicrobial activity of plant extracts was studied at the Microbiological Laboratory of the Department of Genetics, Plant Physiology and Microbiology, Uzhhorod National University, and ${ }^{3}$ Department of Microbiology and Immunology, University of Veterinary Medicine and Pharmacy in Košice.

Biological material samples from the mucous membrane of the nidus of the inflammatory process were taken with the help of a sterile transport system (a test-tube with a gel and applicator for biological liquids, made by FLmedical, Italy). The material was plated on the following nutrient media: Sabouraud Dextrose Agar, and HiCrome ${ }^{\mathrm{TM}}$ Candida Differential Agar (Himedia) for cultivation of microscopic fungi; blood agar for haemolytic microflora, in particular Streptococcus and Neisseria genera microorganisms; Endo and Ploskorev agar (Farmaktiv, Ukraine) for Enterobacteriaceae; Mannitol Salt Agar (Biolif-Italia) for Staphylococcus genus bacteria, Bile esculin agar (Biolif-Italia) for Enterococci. The pure culture of microorganisms was obtained by sector inoculation according to Gold. The bacteria and yeasts were identified based on macromorphological, micromorphological, physiological and biochemical tests with the use of ENTERO-test, STREPTO-test, and STAPHYLO-test, made by Erba Lachema.

Antibiotic susceptibility testing. The antibiotic sensitivity of bacteria and microscopic fungi was identified by the disc diffusion method according to (Order No. 167 of the Ministry of Public Health of Ukraine of 05/04/2007; EUCAST (European Committee on Antimicrobial Susceptibility Testing).

The sensitivity of microorganisms to plant extracts was determined by the agar diffusion test [9]. The bacterium inocula $100 \mu \mathrm{L}$ in the physiological solution were adjusted to the equivalent of $0.5 \mathrm{McFarland}$ standard, and evenly spread on the surface of Muller-Hinton agar (incubated at $37 \pm 2^{\circ} \mathrm{C}$ for 24 hours); 
yeasts - on SDA agar (incubated at $35 \pm 2{ }^{\circ} \mathrm{C}$ for 48 hours). The extracts $20 \mu \mathrm{L}$ were introduced into wells $6 \mathrm{~mm}$ in diameter. The diameters of the inhibition zones were measured in millimetres including the diameter of the well. The antimicrobial effect was assessed by presence of growth inhibition zone. Each antimicrobial assay was performed at least three times.

Antioxidant activity. Detection of free radical scavenging activity of the samples was measured with 2.2-diphenyl-1-picrylhydrazyl (DPPH) [10] (Medini). A sample of $0.1 \mathrm{~mL}$ was mixed with $1.9 \mathrm{~mL}$ of DPPH solution in methanol $\left(0.06 \mathrm{mmol} \mathrm{l}^{-1}\right)$. The absorbance of the reaction mixture was detected with a spectrophotometer Beckman Coulter DU 530. Following incubation in dark for $30 \mathrm{~min}$., the absorbance of each solution was measured at $515 \mathrm{~nm}$ (A). The antioxidant activity was expressed as percentage (\%) of the scavenging activity. The percentage of DPPH radical scavenging activity was calculated by using the following formula:

DPPH radical scavenging activity $(\%)=\frac{\text { Abs }(\text { control })-\text { Abs }(\text { sample })}{\text { Abs }(\text { control })} \times 100$

where Abs (control): Absorbance of DPPH radical + methanol; Abs (sample): Absorbance of DPPH radical + extract.

Determination of Total Tannins (TT). The content of tannins was determined using Folin-Ciocalteus method [12]. The absorbance was measured as the absorbance at $750 \mathrm{~nm}$ (A), with the use of water as the compensation liquid. The percentage of tannins expressed as pyrogallol was calculated based on the following expression:

$$
\text { Tannins }(\%)=\frac{3,125 * \mathrm{~A}}{0,316 * m}
$$

where $\mathrm{m}$ - mass of the sample to be examined, in grams; A - absorbance

The absorbance of the reaction mixture was detected with a spectrophotometer Beckman Coulter DU 530v.

Determination of Total Flavonoids (TF). The flavonoid content was determined by a colorimetric assay as described by aluminium chloride colorimetric method [13] Djeridane. The absorbance of the test solution was measured at $425 \mathrm{~nm}$. with a spectrophotometer Beckman Coulter DU 530.

$$
\mathrm{X}=\frac{\mathrm{A} * 1,25}{m}
$$

where A - absorbance at $425 \mathrm{~nm}$; $\mathrm{m}$ - mass of the herbal drug to be examined in grams.

Statistical analysis. Data obtained were expressed as mean \pm standard deviation (SD) of three measurements. The Tukey's test was applied for comparisons of means; differences were considered significant if $p<0.05$. Statistical analysis and comparisons among means were carried out using Microsoft Excel. The parameters calculated alongside with the basic variation were: average and standard deviation; minimum and maximum coefficients of variation; and frequency of the size of the inhibition zones.

Results. The studies have shown that the extracts displayed antimicrobial activity against Gram-positive bacteria. Ethyl extract of Vaccinium vitis-idaea $L$. fruit was established to display antimicrobial activity against clinical and type strains of S. aureus, B. subtilis, S. pyogenes (Fig. 1, Table 1). Ethyl extract 
of leaves was seen to display a somewhat lower activity against $S$. aureus and S. pyogenes. Similar trends were shown for methyl extract of leaves. Less expressed antimicrobial activity was peculiar for methyl extract of fruit.

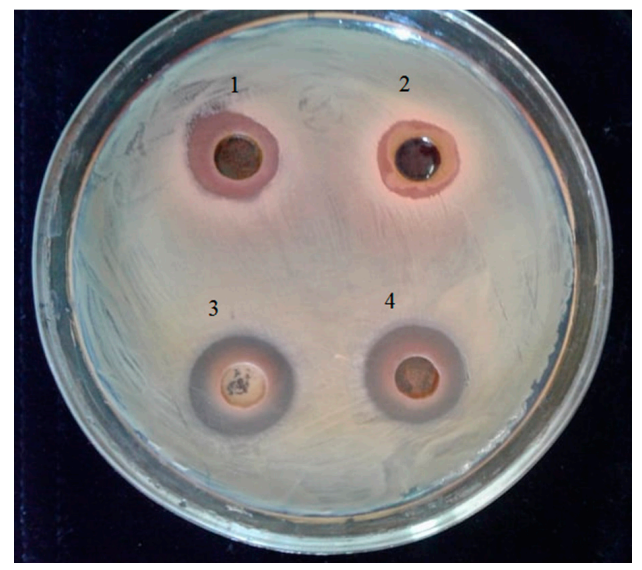

Fig. 1. Antimicrobial activity of Vaccinium vitis-idaea L. extracts against the clinical strain of $S$. aureus:

1 - ethyl extract of leaves; 2 - ethyl extract of fruit; 3 - methyl extract of leaves; 4 - methyl extract of fruit

Thus, the highest antibacterial activity was displayed by the ethyl extract of Vaccinium vitis-idaea L. It is worth noting that the extracts displayed antimicrobial activity against both type and clinical isolates of $S$. aureus, including methicillin-resistant ones. The ethyl fruit extract and methanol leaf extract were established to show antimicrobial effect against $S$. pyogenes. The ethanol fruit and leaf extracts and methanol fruit extract were observed to show weak antimycotic activity. The fruit extracts were characterized by low antimycotic activity.

The extracts were established not to display antimicrobial activity against the probiotic strain of Lactobacillus plantarum (Table 1). Full absence of growth inhibition was registered in case of the use of ethyl and methyl fruit extracts, and low level of antimicrobial activity - in case of the use of ethyl and methyl leaf extracts. The obtained results pointed to the ability of extracts to inhibit the growth of antibiotic-resistant strains of staphylococci and streptococci, without affecting lactobacilli.

The extracts were characterized by high antioxidant activity; the highest activity was displayed by ethyl leaf and fruit extracts, somewhat lower - by methyl extracts (Table 2).

Out of all extracts under review, it was the ethyl fruit extract that showed the highest level of tannins (Table 3). The highest level of flavonoids was registered in the ethyl leaf extract; their quantity in the fruit extracts was 10 times lower. A low level of flavonoids was also registered in the methyl extracts.

The tannic contents of the leaves of ethanol and methanol extracts equaled to $3.906 \%$ and $3.451 \%$, respectively. The lowest level of tannins was peculiar for the methanol fruit extract. The antimicrobial activity of the extracts to a greater extent correlated with the contents of tannins, which was the highest in cowberry (lingonberry) fruit. 
Table 1

Antimicrobial activity of Vaccinium vitis-idaea L. extracts, zones inhibition in millimeters including diameter of well $\mathbf{m m}(\mathbf{n}=3, x \pm \mathrm{SD})$

\begin{tabular}{|l|c|c|c|c|}
\hline Test culture & $\begin{array}{c}\text { ethyl } \\
\text { extract of leaves }\end{array}$ & $\begin{array}{c}\text { ethyl } \\
\text { extract of fruits }\end{array}$ & $\begin{array}{c}\text { methyl extract } \\
\text { of leaves }\end{array}$ & $\begin{array}{c}\text { methyl extract } \\
\text { fruits }\end{array}$ \\
\hline $\begin{array}{l}\text { S.aureus } \\
\text { ATCC 25923 }\end{array}$ & $16.3 \pm 0.5$ & $15.8 \pm 0.5$ & $7.8 \pm 0.8$ & $7.8 \pm 0.3$ \\
\hline S.aureus clinic & $9.5 \pm 0.5$ & $20.3 \pm 0.6$ & $8.2 \pm 0.1$ & $17.2 \pm 0.6$ \\
\hline $\begin{array}{l}\text { S.aureus MRSA } \\
\text { clinic }\end{array}$ & $15.7 \pm 0.6$ & $20.3 \pm 0.6$ & $20.5 \pm 0.8$ & $16.0 \pm 1.0$ \\
\hline $\begin{array}{l}\text { E. coli } \\
\text { ATCC 25922 }\end{array}$ & $7.3 \pm 0.6$ & $6.0 \pm 0.0$ & $6.7 \pm 0.6$ & $6.0 \pm 0.0$ \\
\hline $\begin{array}{l}\text { E. coli } \\
\text { clinic }\end{array}$ & $6.0 \pm 0.0$ & $6.0 \pm 0.0$ & $6.0 \pm 0.0$ & $6.0 \pm 0.0$ \\
\hline $\begin{array}{l}\text { E. faecalis } \\
\text { ATCC 29212 }\end{array}$ & $9.5 \pm 0.3$ & $7.8 \pm 0.3$ & $9.2 \pm 0.6$ & $6.0 \pm 0.0$ \\
\hline E. faecalis clinic & $7.5 \pm 0.8$ & $6.0 \pm 0.0$ & $8.5 \pm 0.5$ & $6.0 \pm 0.0$ \\
\hline B.subtilis & $19.7 \pm 0.6$ & $6.0 \pm 0.0$ & $13.7 \pm 0.6$ & $6.0 \pm 0.0$ \\
\hline $\begin{array}{l}\text { S.pyogenes } \\
\text { ATCC 19615 }\end{array}$ & $14.5 \pm 0.5$ & $20.8 \pm 1.1$ & $24.3 \pm 0.6$ & $17.5 \pm 0.5$ \\
\hline $\begin{array}{l}\text { S.pyogenes } \\
\text { clinic }\end{array}$ & $14.5 \pm 0.5$ & $19.8 \pm 0.8$ & $24.3 \pm 0.6$ & $17.3 \pm 0.6$ \\
\hline $\begin{array}{l}\text { C.albicans } \\
\text { ATCC 885-653 }\end{array}$ & $10.3 \pm 0.3$ & $9.2 \pm 0,3$ & $6.0 \pm 0.0$ & $9.8 \pm 0.3$ \\
\hline $\begin{array}{l}\text { Lactobacillus } \\
\text { plantarum }\end{array}$ & $7.5 \pm 0.8$ & $6.0 \pm 0.0$ & $13.7 \pm 0.6$ & $6.0 \pm 0.0$ \\
\hline
\end{tabular}

«6» - diameter of well, means no inhibition; control of ethanol - no inhibition; control of methanol no inhibition.

Table 2

Antioxidant activity of Vaccinium vitis-idaea L. extracts

\begin{tabular}{|l|c|c|c|c|}
\hline \multirow{2}{*}{ Екстракт } & \multicolumn{2}{|c|}{ ethyl extract } & \multicolumn{2}{c|}{ methyl extract } \\
\cline { 2 - 5 } & Absorbance (nm) & $\%$ & Absorbance (nm) & $\%$ \\
\hline Vaccinium vitis-ideae L. (leaves) & 0.493 & 97.2 & 0.073 & 85.2 \\
\hline Vaccinium vitis-ideae L. (fruit) & 0.073 & 85.2 & 0.109 & 77.9 \\
\hline
\end{tabular}

Table 3

Level of tannins and flavonoids in ethyl and methyl fruit and leaf extracts of Vaccinium vitis-idaea $L$.

\begin{tabular}{|l|c|c|c|c|}
\hline \multirow{2}{*}{ Extract } & ethyl extract & \multicolumn{2}{c|}{ methyl extract } \\
\cline { 2 - 5 } & Absorbance (nm) & $\%$ & Absorbance (nm) & $\%$ \\
\hline \multicolumn{5}{|c|}{ tannins } \\
\hline Vaccinium vitis-ideae L. (leaves) & 0.395 & 3.9 & 0.349 & 3.5 \\
\hline Vaccinium vitis-ideae L. (fruit) & 0.814 & 8.3 & 0.155 & 1.5 \\
\hline \multicolumn{5}{|c|}{ flavonoids } \\
\hline Vaccinium vitis-ideae L. (leaves) & 0.164 & 0.21 & 0.058 & 0.8 \\
\hline Vaccinium vitis-ideae L. (fruit) & 0.022 & 0.03 & 0.019 & 0.1 \\
\hline
\end{tabular}


The antimicrobial and high antioxidant activity of ethanol extract of Vaccinium vitis-idaea $L$. fruit, and at the same time absence of the antimicrobial activity against the probiotic strain of Lactobacillus plantarum, characterized by the antagonistic activity against opportunistic microorganisms, cause the advisability of their complex application as the basis for phytobiotics.

Discussion. Genus Vaccinium L. includes around 450 species found mostly in the northern hemisphere of our planet. Fruit and leaves of these Vaccinium species produce a wide range of compounds: flavonoids such as anthocyanins, flavonols, flavanols (catechins), phenolic acids (benzoic and cinnamic acid derivatives), chromones, coumarins, lignans, iridoids, sterols, and triterpenoids. The principal components are flavonoids (anthocyanins). Extracts of anthocyanins from Vaccinium fruit and leaves demonstrate various pharmacological effects such as antidiabetic, anti-inflammatory, vasoprotective, antimicrobial, antitumor, gene-protective, and antioxidative [13].

We have shown the antimicrobial activity of cowberry extracts to correlate with the data presented by other scholars. There are data proving that Vaccinium vitis-idaea L. has an antimicrobial effect upon the microorganisms isolated from the human oral cavities, in particular, Streptococcus mutans and Fusobacterium nucleatum. We have also ascertained the antimicrobial activity of plant extracts against Bacillus cereus, Staphylococcus aureus, Serratia marcescens, Pseudomonas aeruginosa, Bacillus subtilis, and Listeria monocytogenes [14].

The results of the study presented in [15] showed a stronger antibacterial effect of cowberry samples on Gram-negative bacteria, especially on Pseudomonas fluorescens and Pseudomonas aeruginosa. The results confirmed that Vaccinium vitis-idaea fruit belonging to different growing sites differed from each other in terms of bioactive compounds in quantity and activity. At the same time, there exist data proving the antimicrobial activity of cowberry extract against the Gram-positive culture of Mycobacterium luteum and Staphylococcus aureus [16]. The antibiofilm activity of cowberry flavonoids against oral pathogens has also been established [17].

The sensitivity of $S$. aureus to the extracts was shown to vary from $15.8 \pm$ $\pm 0.5 \mathrm{~mm}$ (a type strain) to $20.3 \pm 0.6 \mathrm{~mm}$ (a clinical methicillin-resistant strain). Other authors also pointed to similar trends of more distinguished antimicrobial activity of extracts of medicinal plants (Acacia catechu, Garcinia mangostana) against methicillin-resistant strains of S.aureus, as compared with type strains [18].

Most plants contain several compounds with antimicrobial properties for protection against aggressor agents, especially microorganisms. Plant secondary metabolites are mostly responsible for their antimicrobial activity. Major groups of phytochemicals that possess antimicrobial properties are phenolics and polyphenols (flavonoids, quinones, tannins, coumarins), terpenoids, alkaloids, lectins and polypeptides [17]. 
The literary review [19] (Cowan, M. M. (1999) analyzed a set of known biologically active substances contained by plants, and the mechanism of their antimicrobial activity. In particular, the authors noted the antimicrobial activity of tannins and flavonoids. The works [20] (Hayashi et al., 2008) showed that tannins from Vaccinium vitis-idaea have antibacterial effects against Porpyromonas ginigivalis and Prevotella intermedia, and inhibitory effect against Listonella anguillarum (serotypes $\mathrm{O} 1$ and $\mathrm{O} 2$ ), Yersinia ruckeri, Photobacterium damselae subsp. piscicida and Lactococcus garvieae [21, 22]. Anthocyans of Vaccinium genus plants were established to be not only food products but also therapeutic agents. The selected literature data on anthocyanins raised the hope for their wide-spread use for the prevention and therapy of many diseases [14]. In our preceding works, we showed the antimicrobial activity of materials obtained from vegetable matter, phytoextracts and essential oils that showed the antimicrobial activity against isolates from the oral cavity, pharynx, and respiratory tract, including antibiotic-resistant ones [23-26].

The antimicrobial and high antioxidant activity of the ethanol extract of Vaccinium vitis-idaea $\mathrm{L}$. fruit and leaves, and absence of the antimicrobial effect against the probiotic strain of Lactobacillus plantarum, characterized by the antagonistic activity against opportunistic microorganisms, cause the advisability of their complex application as the basis for phytobiotics. Both recent works and our previous studies have shown that generalised periodontitis is complicated by persistence of associations of opportunistic antibiotic-resistant microorganisms [27]. A positive impact of the application of probiotics, including based on lactobacilli, for inflammatory diseases of the oral cavity including generalised periodontitis, has also been described [28]. This is why, it remains promising to explore a possibility of complex use of compositions based on extracts of Vaccinium vitis-idaea L. and probiotic reduction of persistence of opportunistic microorganisms due to additive effect.

Conclusion. Thus, we have shown the antimicrobial activity of Vaccinium vitis-idaea $L$. fruit and leave extracts against type and clinical isolates of $S$. aureus, including methicillin-resistant ones, and against $S$. pyogenes. Weak antimycotic activity of ethanol extracts of cowberry fruit and leaves has been revealed, and high antioxidant activity of their ethyl extracts has been shown. The antimicrobial activity of the extracts to a greater extent correlated with the contents of tannins, which was the highest in cowberry fruit. The established regularities cause good prospects for further studies of the use of Vaccinium vitis-idaea $L$. as a source of substances with antimicrobial activity against antibiotic-resistant representatives of opportunistic microbiota.

This publication was supported by the Slovak Research and Development Agency under the Contract No. APVV-15-0377. 


\title{
АНИМІКРОБНІ, АНТИОКСИДАНТНІ ТА ДЕЯКІ БІОХІМІЧНІ ВЛАСТИВОСТI VACCINIUM VITIS-IDAEA L.
}

\author{
М.В. Кривцова ${ }^{1}$, К. Труші, С. Ефтімова ${ }^{2}$ Я. Кощова ${ }^{2}$, М.Я. Співак
}

\author{
${ }^{1}$ ДВНЗ «Ужгородський національний університет», \\ вул.Волочина, 32, Ужгород, 88000, Украӥна \\ ${ }^{2}$ Університет ветеринарної медицини та фармації в Кошицее, \\ вул. Коменського, 73, Кошице, 04181, Словакія \\ ${ }^{3}$ Інститут мікробіологї і вірусологї ім. Д.К. Заболотного НАН Украӥни, \\ вул. Академіка Заболотного, 154, Київ, 03143, Украӥна

\section{Резюме}

Протягом останніх років інтерес до рослинної сировини з точки зору потенційної антимікробної активності стрімко зростає. Екстракти з рослин роду Vaccinium володіють цілим спектром біологічно активних речовин, які характеризуються протизапальними, антидіабетичними, генопротекторними, антиоксидантними та антимікробними властивостями. Метою роботи було дослідити антимікробні, антиоксидантні та деякі біохімічні властивості спиртових екстрактів плодів та листків Vaccinium vitis-idaea L., зібраних в умовах Українськиї Карпат. Методи. Рослини для досліджень були зібрані в околицях села Пилипець Міжгірського району Закарпатської області. 3 листків та плодів були виготовлені етилові та метилові екстракти. Досліджено антиоксидантну активність (DPPH-методом), загальний вміст танінів та флавоноїдів - спектрофотометричним методом, антимікробну активність - методом дифузії в агар. Для досліджень були використані типові та клінічні ізоляти, виділені із ротової порожнини людей із запальними захворюваннями пародонту, що характеризуються широким спектром резистентності до антибіотиків. Результати. Досліджені екстракти показали антимікробну активність у більшій мірі на грампозитивні бактерії. Найвищу антибактеріальну дію проявляв етиловий екстракт плодів Vaccinium vitis-idaea L. Антимікробну дію реєстрували як на типові, так і клінічні ізоляти $S$. aureus, в тому числі метицилінрезистентні. Встановлена висока антимікробна активність етилового екстракту плодів та метилового екстракту листків на S. pyogenes. Виявлена слабка протигрибкова активність етилових екстрактів плодів та листків і метилового екстракту плодів. Екстракти характеризувались високою антиоксидантною активністю, при цьому найвище ії значення було характерне для етилових екстрактів листків та плодів, дещо нижче - метилових. Найвищий рівень танінів із всіх досліджених екстрактів був характерний для етилового екстракту плодів. Антимікробна активність екстрактів більшою мірою корелювала з вмістом танінів, рівень яких був найвищим для плодів брусниці. Висновки. Антимікробна та висока антиоксидантна активність етилового екстракту плодів Vaccinium vitis-idaea L. та одночасна відсутність антимікробної дії на пробіотичний штам Lactobacillus plantarum, який характеризується антагоністичною активністю щодо умовно-патогенних мікроорганізмів, обумовлює доцільність їх комплексного застосування як основи фітобіотика.

Ключові слова: антимікробні властивості, антиоксидантна активність, флавоноїди, таніни, Vaccinium vitis-idaea L. 


\title{
АНИМИКРОБНЫЕ, АНТИОКСИДАНТНЫЕ И НЕКОТОРЫЕ БИОХИМИЧЕСКИЕ СВОЙСТВА VACCINIUM VITIS-IDAEA L.
}

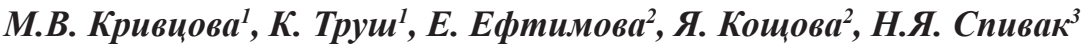

\author{
${ }^{1}$ ГВУЗ «Ужгородский национальный университет», \\ ул. Волошина, 32, Ужгород, 88000, Украина \\ ${ }^{2}$ Университет ветеринарной медицины и фармации в Кошице, \\ ул. Коменского, 73, Кошице, 04181, Словакия \\ ${ }^{4}$ Институт микробиологии и вирусологии им. Д.К. Заболотного НАН Украины, \\ ул. Академика Заболотного, 154, Киев, 03143, Украина
}

\section{Резюме}

В последние годы интерес к растительному сырью с точки зрения потенциальной антимикробной активности стремительно возрастает. Экстракты из растений рода Vaccinium обладают целым спектром биологически активных веществ, которые характеризуются противовоспалительными, противодиабетическими, генопротекторными, антиоксидантными и антимикробными свойствами. Целью работы было исследовать антимикробные, антиоксидантные и некоторые биохимические свойства спиртовых экстрактов плодов и листьев Vaccinium vitis-idaea L., собранных в условиях Украинских Карпат. Методы. Растения для исследований были собраны в окрестностях села Пилипец Межгорского района Закарпатской области. Из листьев и плодов были изготовлены этиловые и метиловые экстракты. Исследована антиоксидантная активность (DPPH-методом), общее содержание танинов и флавоноидов спектрофотометрическим методом, антимикробная активность методом диффузии в агар. Для исследований были использованы эталонные и клинические изоляты, выделенные из ротовой полости людей с воспалительными заболеваниями пародонта, характеризующиеся широким спектром резистентности к антибиотикам. Результаты. Исследованные экстракты показали антимикробную активность в большей степени на грамположительные бактерии. Наивысшее антибактериальное действие проявлял этиловый экстракт плодов Vaccinium vitis-idaea L. Антимикробное действие регистрировали как на эталонные, так и клинические изоляты $S$. aureus, в том числе метициллинрезистентные. Установлена высокая антимикробная активность этилового экстракта плодов и метилового экстракта листьев на $S$. pyogenes. Обнаружена слабая противогрибковая активность этиловых экстрактов плодов и листьев и метилового экстракта плодов. Экстракты характеризовались высокой антиоксидантной активностью, при этом высокое ее значение было характерно для этилового экстракта листьев и плодов, несколько ниже - метиловых. Самый высокий уровень танинов из всех исследованных экстрактов был характерен для этилового экстракта плодов. Антмикробная активность экстрактов в большей степени коррелировала с содержанием танинов, уровень которых был самым высоким для плодов брусники. Выводы. Антимикробная и высокая антиоксидантная активность этилового экстракта плодов Vaccinium vitis-idaea L. и одновременно отсутствие антимикробного действия на пробиотический штамм Lactobacillus plantarum, который характеризуется антагонистической активностью по отношению к условно-патогенным микроорганизмам, обусловливает целесообразность их комплексного применения как основы фитобиотика.

Ключевые слова: антимикробные свойства, антиоксидантная активность, флавоноиды, танины, Vaccinium vitis-idaea L. 
1. Tapalsky D., Tapalsky F. Antibakterialnaya aktivnost ofitsinalnykh lekarstvennykh rasteniy v otnoshenii ekstremalno-antibiotikorezistentnykh gramotritsatelnykh bakteriy (Antibacterial activity of officinal medicinal plants against extremely antibioticresistant Gram-negative bacteria). Problemy zdorovia i ekologii (Problems of Health and Ecology). 2015; 4 (46):69-74. Russian.

2. Ryzhov V., Ryzhova Ye., Korotky V., Yesipovich A., Kazantsev O., Zenkin A. Khvoinoenergeticheskaya kormovaya dobavka dlia zhivotnovodstva (Coniferous energy feed supplement for cattle-breeding). Nauchno-metodicheskiy elektronnyi zhurnal "Kontsept" (Scientific methodological journal "Concept"). 2014; 26:431-435. Russian

3. Suchasnyi stan i perspektyvy zastosuvannia preparativ iz roslyn rodyny khvoinykh u veterynarniy praktytsi (Contemporary situation and prospects for application of Pinaceae-based preparations in veterinary practice) [Text] / Kotsiumbas I. [et al.]. Naukovotekhnichnyi biuleten: zb. prats (Scientific and Technical Bulletin: Selected Papers). Institute of Animal Biology, State Scientific Research and Controlling Institute of Veterinary Preparations and Feed Supplements. 2012; 3-4 (13):428-436.

4. Basam Basim Al-Fraji, Enas Ibrahim Jasim, Rasha Mohamed Sajet, Enaam Hameed Batah. Effects of some traditional plants extracts on bacteria isolated from burns, wounds skin diseases. World Journal of Pharmaceutical Research. 2016; 5(6):63-74.

5. Vunnava A. Anthelminthic and antibacterial activity of various. Indians medicinal plants. Medicinal \& Aromatic Plants. 2014; 3(4). http://dx.doi.org/10.4172/21670412.1000167 .

6. Ali M., Abbasi B.H., Ahmad N., Khan H., Ali G.S. Strategies to enhance biologically active-secondary metabolites in cell cultures of Artemisia - current trends. Critical Reviews in Biotechnology. Informa UK Limited. 2017; 37(7):833-851. http://dx.doi. org/10.1080/07388551.2016.1261082

7. Abuhamdah S. Phytochemical investigations and antibacteril activity of selected medicinal plants from Jordan. European Journal of Medicinal Plants. 2013; 3(3):394404. http://dx.doi.org/10.9734/ejmp/2013/3540.

8. Resipe of primary deposition of a microorganism strain with the Depositary of the Zabolotny Institute of Microbiology and Virology, National Academy of Sciences of Ukraine. Tymoshok N., Lazarenko L., Babenko L., Demchenko O., Bubnov R., Kryvtsova M., Spivak M. Lactobacillus plantarum 77/5. Ukrainian.

9. Balouiri M., Sadiki M., Ibnsouda S.K. Methods for in vitro evaluating antimicrobial activity: A review. Journal of pharmaceutical analysis. 2016; 6(2):71-79. doi:10.1016/j. jpha.2015.11.005 10.

10. Medini F., Fellah H., Ksouri R., Abdelly C. Total phenolic, flavonoid and tannin contents and antioxidant and antimicrobial activities of organic extracts of shoots of the plant Limonium delicatulum. Journal of Taibah University for Science. 2014; 8(3):216-224. doi:10.1016/j.jtusci.2014.01.003.

11. Ganjiwale R., Wadher S., Yeole P., Polshettiwar S. Spectrophotometric estimation of total tannins in some ayurvedic eye drops. Indian Journal of Pharmaceutical Sciences. OMICS Publishing Group; 2007; 69(4):574.

12. Djeridane, A., Yous, M.; Nadjemi, B.; Boutassouna, D.; Stocker, P.; Vidal, N. Antioxidant activity of some Algerian medicinal plants extracts containing phenolic compounds. Food Chem. 2006; 97:654-660. 
13. Karcheva-Bahchevanska D., Lukova P., Nikolova M., Mladenov R., Iliev I. Theraputic effects of anthocyans from Vaccinium genus L. International Journal of Medical Research and Pharmaceutical Sciences. 2017; 4(6):1-9. doi: 10.5281/zenodo.809201.

14. Karcheva-Bahchevanska D., Lukova P., Nikolova M., Mladenov R., Iliev I., Laslo É., Köbölkuti Z.A. Total Phenol Content and Antimicrobial Activity of Lingonberry (Vaccinium vitis-idaea L.) from Several Areas in the Eastern Carpathians. Notulae Scientia Biologicae. 2017; 9(1):77. doi:10.15835/nsb9110035.

15. Laslo É., Köbölkuti Z.A. Total Phenol Content and Antimicrobial Activity of Lingonberry (Vaccinium vitis-idaea L.) from Several Areas in the Eastern Carpathians. Notulae Scientia Biologicae. Academic Press (EAP) Publishing House. 2017; 9(1):77-83. http://dx.doi.org/10.15835/nsb9110035.

16. Stadnytska N., Komarovska-Porokhniavets O., Kishchak Kh., Mykoliv O., Lytvyn B., Konechna R., Novikov V. Roslyny z protymikrobnymy vlastyvostiamy (Plants with antimicrobial properties). Visnyk Natsionalnoho universytetu "Lvivska politekhnika" (Bulletin of the National University 'Lviv Polytechnics'). 2011;700: Chemistry, technology of substances and their use. 111-116. Ukrainian.

17. Riihinen K.R., Ou Z.M., Gödecke T., Lankin D.C., Pauli G.F., Wu C.D. The antibiofilm activity of lingonberry flavonoids against oral pathogens is a case connected to residual complexity. Fitoterapia. 2014; 97:78-86. http://dx.doi.org/10.1016/j.fitote.2014.05.012

18. Voravuthikunchai S.P., Kitpipit, L. Activity of medicinal plant extracts against hospital isolates of methicillin-resistant Staphylococcus aureus. Clinical Microbiology and Infection. 2005; 11(6):510-512. http://dx.doi.org/10.1111/j.1469-0691.2005.01104.x.

19. Ginovyan M., Petrosyan M., Trchounian A. Antimicrobial activity of some plant materials used in Armenian traditional medicine. BMC Complementary and Alternative Medicine. 2017; 17(1). doi:10.1186/s12906-017-1573-y.

20. Cowan M.M. Plant products as antimicrobial agents. Clinical microbiology reviews. American society for microbiology. 1999; 12(4):564-82. http://dx.doi.org/10.1128/ cmr.12.4.564.

21. Hayashi S., Funatogawa K., Yoshikazu H. Antibacterial effects of tannins in childrens and adults. Botanical medicine in clinical practice. CABI. 2008;141-151.

22. Ho K.Y., Tsai C.C., Huang J.S., Chen C.P., Lin T.C., Lin C.C. Antimicrobial activity of tannin components from Vaccinium vitis-idaea L. Journal of Pharmacy and Pharmacology. 2001; 53(2):187-91. http://dx.doi.org/10.1211/0022357011775389.

23. Kryvtsova, M.V, Kohuch T.T., Salamon I., Spivak M.J. Antimicrobial activity of some essential oils on Candida genus clinical isolates. Mikrobiol Zh. 2018; 80(4):3-12. doi:10.15407/microbiolj80.04.003.

24. Kryvtsova M., Livak O., Balabanska B., Marochka N., Bilak O., Hanych T. Antibakterialna diya efirnykh oliy na klinichni izoliaty zbudnykiv oportunistychnykh infektsiy (Antimicrobial effect of essential oils upon clinical isolates of agents of opportunistic infections). Naukovyi visnyk Uzhhorodskoho universitetu (Scientific Bulletin of Uzhhorod University). Series: Biology. 2017; 42:82-85. Ukrainian

25. Kryvtsova M., Salamon I. Susceptibility of opportunistic pathogenic microorganisms to plant essential oils. In: The $4^{\text {th }}$ International Mediterranean Symposium on Medicinal and aromatic plants. 2018, April 18-22, Antalya, Tukrey. p. 46. 
26. Salamon I., Kryvtsova M., Bucko D., Tarawneh Amer H. Chemical characterization and antimicrobial activity of some essential oils after their industrial large-scale distillation. The Journal of Microbiology, Biotechnology and Food Sciences. 2018; 8(3):965-969. doi: 10.15414/jmbfs.2018.8.3.965-969

27. Kostenko O., Kryvtsova M., Kostenko Ye., Savchuk O. Analiz dominuyuchykh mikrobnykh asotsiatsiy porozhnyny rota ta osoblyvosti yikh chutlyvosti do antybakterialnykh ta antyseptychnykh preparativ (Analysis of dominating microbial associations of oral cavity and perculiarities of their sensitivity to antibacterial and antiseptic preparations). Suchasna stomatolohiya (Contemporary Dentistry). 2018; 5(94):40-43.

28. Mykytenko A. Novi perspektyvy vykorystannia multyprobiotyka "Simbiter Omega" dlia monoterapiyi khronichnoho heneralizovanoho parodontytu (New prospects for the use of Simbiter Omega probiotic material for monotherapy of chronic generalized periodontitis. Aktualni problemy suchasnoyi medytsyny: Visnyk ukrayiskoyi medychnoyi stomatolohichnoyi akademiyi (Actual problems of contemporary medicine: Bulletin of the Ukrainian Medical Dental Academy). 2014; 4(14):23-25. Ukrainian.

Отримано 19.02.2019 